\title{
PENGARUH TOTAL ASSET TURN OVER, CURRENT RATIO, DEBT TO EQUITY RATIO DAN RETURN ON ASSETS TERHADAP KEBIJAKAN DIVIDEN (STUDI PADA PERUSAHAAN YANG TERMASUK DALAM INDEKS INVESTOR33 PERIODE TAHUN 2015-2017)
}

\author{
${ }^{1}$ Bawon Triono, ${ }^{2}$ Dwi Artati \\ S1 Manajemen, Sekolah Tinggi Ilmu Ekonomi Putra Bangsa Kebumen \\ e-mail: bawontriono041@gmail.com
}

\begin{abstract}
This study aimed to examine and analyze the effect of Total Asset Turn Over (TATO), Current Ratio (CR), Debt to Equity Ratio (DER) and Return On Assets (ROA) on Dividend Policy in companies included in Investor33 index 2015-2017. The sampling technique used a purposive sampling method, which is a sampling technique based on a certain criterion, so as to get a sample of 19 companies from a total population of 33 companies. The results of this study indicated that the total asset turnover variable has a positive effect on the company's dividend policy, the current ratio variable has a negative effect on the company's dividend policy, the debt to equity ratio variable has a negative effect on the company's dividend policy, the return variable on assets has a positive effect on the company's dividend policy, and the four variables also influence jointly on the company's dividend policy.
\end{abstract}

Keywords: Total Asset Turn Over (TATO), Current Ratio (CR), Debt to Equity Ratio (DER), Return On Assets (ROA), and Dividend Policy

\begin{abstract}
Abstrak: Penelitian ini bertujuan untuk menguji dan menganalisis pengaruh Total Asset Turn Over (TATO), Current Ratio (CR), Debt to Equity Ratio (DER) dan Return On Assets (ROA) terhadap Kebijakan Dividen pada perusahaan yan termasuk dalam indeks Investor33 tahun 2015-2017. Teknik pengambilan sampel menggunakan metode purposive sampling, yaitu teknik pengambilan sampel berdasarkan suatu kriteria tertentu, sehingga didapatkan sampel sebanyak 19 perusahaan dari total populasi 33 perusahaan. Hasil penelitian ini menunjukkan bahwa variabel total asset turn over berpengaruh positif terhadap kebijakan dividen, variabel current ratio berpengaruh negatif terhadap kebijakan dividen, variabel debt to equity ratio berpengaruh negatif terhadap kebijakan dividen, variabel return on assets berpengaruh positif terhadap kebijakan dividen, serta keempat variabel juga berpengaruh secara bersama-sama terhadap kebijakan dividen.
\end{abstract}

Kata kunci: Total Asset Turn Over (TATO), Current Ratio (CR), Debt to Equity Ratio (DER), Return On Assets (ROA), dan Kebijakan Dividen

\section{PENDAHULUAN}

Perusahaan pada umumnya ingin mencapai profitabilitas maksimal dari modal yang diinvestasikan. Laba atau profitabilitas ini dapat digunakan untuk mencapai tujuan perusahaan seperti kelangsungan hidup dan pertumbuhan perusahaan. Selain itu perusahaan juga ingin meningkatkan kesejahteraan anggotanya, yaitu dengan cara membagikan dividen kepada investor. Hal tersebut selaras dengan tujuan para investor yaitu memperoleh return yang maksimal dari dana yang di investasikan baik berupa capital gain atau dividen.

Investor pada umumnya menginginkan dividen perusahaan yang stabil dan cenderung meningkat. Namun, tidak semua perusahan mampu membagikan dividen secara stabil. Hal tersebut tentunya dipengaruhi oleh berbagai faktor yang menjadikan pembagian dividen tidak stabil. Penelitian ini akan berusaha menganalisis 
${ }^{1}$ Bawon Triono, ${ }^{2}$ Dwi Artati

faktor-faktor apa saja yang dapat mempengaruhi kebijakan dividen pada perusahaan yang termasuk dalam indeks Investor 33 tahun 2015-2017. Kebijakan Dividen pada penelitian ini diukur dengan Dividend Payout Ratio (DPR).

\section{Tabel I.1}

Persentase Tingkat Pembayaran Dividen

Pada Indeks Investor 33 yang Terdaftar di

Bursa Efek Indonesia Tahun 2015 -2017

\begin{tabular}{|c|c|c|c|c|}
\hline \multirow{2}{*}{ No } & \multicolumn{2}{|l|}{ Kode } & \multicolumn{2}{|l|}{ Tahun } \\
\hline & Perusahaan & 2015 & $\underline{2016}$ & $\underline{2017}$ \\
\hline 1 & AMRT & 40.04 & 30.03 & $\overline{30.01}$ \\
\hline 2 & ICBP & 49.75 & 24.94 & 49.76 \\
\hline 3 & JSMR & 20.24 & 29.99 & 20.00 \\
\hline 4 & UNTR & 66.89 & 10.66 & 65.65 \\
\hline 5 & WSKT & 20.00 & 28.35 & 18.48 \\
\hline
\end{tabular}

Sumber: Idx data diolah, 2019

Tabel I.1 menunjukkan bahwa nilai DPR pada beberapa perusahaan yang termasuk dalam indeks Investor 33 masih mengalami flukluasi pada setiap tahunnya. Penurunan pembayaran dividen tersebut menjadi menarik untuk diteliti karena kontradiktif dengan kenaikan laba bersih perusahaan pada tahun penurunan pembayaran dividen dengan tahun sebelumnya. Salah satu contoh kontradiksimengenai tingkat pembayaran dividen dengan nilai laba bersih adalah PT Sumber Alfaria Trijaya Tbk. pada tahun 20152016 mengalami penurunan rasio pembayaran dividen sebesar $10,01 \%$, padahal di periode tahun yang sama nilai laba bersihnya mengalami kenaikan yaitu dari 464 miliar rupiah menjadi 554 miliar rupiah. Hal serupa juga terjadi pada PT Jasa Marga (Persero) Tbk. pada periode tahun 2016 - 2017 terjadi penurunan rasio pembayaran dividen sebesar 9,99\%, sedangkan pada periode tahun yang sama perusahaan tersebut menghasilkan laba bersih senilai Rp 1,80 triliun pada tahun 2016, kemudian laba bersih perusahaan naik menjadi Rp 2,09 triliun pada tahun 2017 (www.idx.co.id). Kebijakan Dividen dipengaruhi oleh berbagai faktor, antara lain yang dikemukakan oleh (Husnan, 2006:297) bahwa kebijakan dividen itu dipengaruhi oleh operating cash flow, tingkat laba,kesempatan investasi, biaya transaksi, dan pajak perorangan. Sedangkan menurut Margaretha (2005:148), faktor faktor yang mempengaruhi kebijakan dividen adalah likuiditas, peluang investasi, leverage dan arus kas. Penelitian ini berupaya mempelajari beberapa faktor yang dapat dijadikan sebagai alat prediksi tentang tingkat pengembalian investasi berupa pendapatan deviden. Faktor-faktor yang diteliti adalah Total Asset Turn Over (TATO), Current Ratio (CR), Debt to Equity Ratio(DER) dan Return On Asset (ROA).

Penelitian mengenai faktor-faktor yang mempengaruhi kebijakan dividen telah banyak dilakukan, namun terdapat ketidakkonsistenan atas hasil penelitian. Hasil penelitian yang dilakukan oleh Rahmawati et al. (2014) menyatakan bahwa total asset turn over berpengaruh signifikan terhadap kebijakan dividen. Namun, berbeda dengan penelitian Nurhayati (2015) yang menyatakan bahwa total asset turn over tidak berpengaruh terhadap kebijakan dividen.

Hasil penelitian lain mengenai hubungan curren ratio dan kebijakan dividen. Penelitian Sanjari (2014) menyatakan bahwa likuiditas yang diukur dengan current ratio dan quick test ratio berpengaruh positif terhadap kebijakan dividen. Namun penelitian Nurhayati (2013), menyebutkan bahwa variabel current ratio tidak berpengaruh terhadap kebijakan dividen. Penelitian Silviana et al, (2014) menyatakan bahwa debt to equity ratio berpengaruh signifikan terhadap kebijakan dividen. Namun terjadi perbedaan pada penelitian Wati (2015), mengungkapkan bahwa variabel debt to equity ratio tidak berpengaruh terhadap kebijakan dividen. Penelitian Sanjari (2014) mengungkapkan bahwa Return On Assets berpengaruh terhadap kebijakan dividen. Sedangkan menurut penelitan Rahawati (2015) Return On Assets tidak berpengaruh terhadap kebijakan dividen.

Berdasarkan pemaparan latar belakang di atas, maka penulis tertarik untuk melakukan penelitian dengan mengambil judul "Pengaruh Total Asset Turn Over, Current Ratio, Debt to Equity Ratio, dan Return On Assets Terhadap Kebijakan Dividen. (Studi pada Perusahaan yang Termasuk dalam Indeks Investor33 Periode Tahun 2015 - 2017)" 
${ }^{1}$ Bawon Triono, ${ }^{2}$ Dwi Artati

\section{TELAAH PUSTAKA DAN HIPOTESIS}

\section{Teori Keagenan}

Menurut Husnan dan Pudjiastuti (2006:12), bagi perusahaan yang berbentuk Perseroan Terbatas, sering kali terjadi pemisahan antara pengelolaan perusahaan dengan pemilik perusahaan. Dengan demikian memungkinkan munculnya berbagai masalah atau konflik keagenan. Konflik yang paling sering terjadi di sini adalah konflik yang berkaitan dengan kepentingan masing-masing pihak. Perbedaan kepentingan antara pemilik dan agen adalah salah satunya pemicunya. Kepentingan pemilik untuk mengikatkan nilai perusahaan (harga saham) berbenturan dengan kepentingan manajemen yang menjalankan perusahaan untuk memperoleh imbalan yang sebesar-besarnya dari pemilik. Manajer seringkali menjalankan perusahaan tanpa memperhatikan risiko yang nantinya akan ditanggung oleh pemilik.

\section{Kebijakan Dividen}

Kebijakan divien merupakan keputusan untuk membagi laba yang diperoleh perusahaan kepada pemegang saham sebagai dividen atau akan menahan dalam bentuk laba ditahan untuk digunakan sebagai pembiayaan investasi di masa yang akan datang. Indikator kebijakan dividen yang digunakan yaitu Dividend Payout Ratio. Menurut Prastowo (2011:104), Dividend Payout Ratio mengukur laba bersih per satu lembar saham biasa yang akan dibayarkan dalam bentuk dividen. Rumus Dividend Payout Ratio:

$$
\text { Dividen Payout Ratio }=\frac{\text { Dividen Per Share }}{\text { Earning Per Share }}
$$

\section{Total Asset Turn Over}

Perputaran Aset (Total Asset Turn Over) merupakan rasio yang digunakan untuk mengukur perputaran semua aktiva yang dimiliki perusahaan dan mengukur berapa jumlah penjualan yang diperoleh dari tiap rupiah aktiva (Kasmir, 2012:185). Semakin besar rasio perputaran aset akan semakin baik karena perusahan diangap efektif dalam mengelola aset yang dimilikinya. Rumus Total Asset Turn Over (TATO):

$$
\text { TATO }=\frac{\text { Penjualan }}{\text { Total Aktiva }}
$$

\section{Current Ratio}

Current Ratio (CR) atau rasio lancar merupakan rasio untuk mengukur kemampuan perusahaan dalam membayar kewajiban jangka pendek atau utang yang segera jatuh tempo pada saat ditagih secara keseluruhan (Kasmir, 2015:134). Rumus current ratio adalah:

$$
\text { Current Ratio }=\frac{\text { Current Asset }}{\text { Current Liability }}
$$

\section{Debt to Equity Ratio}

Debt to Equity Ratio (DER) berfungsi untuk mengetahui jumlah dana yang disediakan peminjam atau kreditur dengan pemilik perusahaan (Kasmir,2012:151). Rasio ini merupakan perbandingan antara total utang dengan ekuitas, dengan kata lain rumus dari rasio debt to equity ratio menurut (Kasmir, 2012:151) yaitu:

$$
D E R=\frac{\text { Total Hutang }}{\text { Ekutitas }}
$$

\section{Return On Assets}

Menurut Hanafi dan Halim (2014:157) Return On Asset (ROA) merupakan rasio yang digunakan untuk mengukur kemampuan perusahaan dalam menghasilkan laba bersih berdasarkan tingkat aset tertentu. Semakin besar ROA, semakin besar pula tingkat keuntungan yang dicapai oleh perusahaan. Selain itu, rasio return on asset yang tinggi juga menggambarkan produktivitas perusahaan semakin baik. Rumus dari rasio ini adalah sebagai berikut :

$$
\text { ROA }=\frac{\text { Laba Bersih }}{\text { Total Aset }}
$$


${ }^{1}$ Bawon Triono, ${ }^{2}$ Dwi Artati

\section{Model Penelitian}

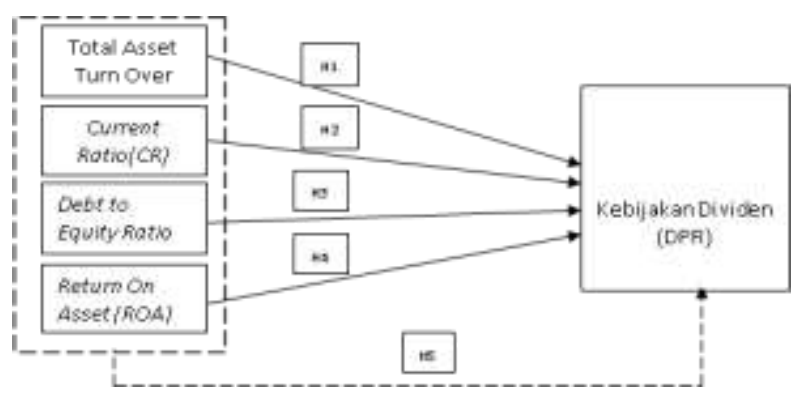

Gambar II-1 Model Penelitian

\section{Hipotesis Penelitian}

H1:Total asset turn over berpengaruh terhadap kebijakan dividen.

$\mathrm{H} 2$ : Current ratio berpengaruh terhadap kebijakan dividen.

H3:Debt to equity ratio berpengaruh terhadap kebijakan dividen.

H4:Return on assets berpengaruh terhadap kebijakan dividen.

H5:Total asset turn over, current ratio, debt to equity ratio, dan return on assets secara bersama -sama berpengaruh terhadap kebijakan dividen.

\section{Metodologi Penelitian}

Populasi dalam penelitian ini merupakan perusahaan yang termasuk dalam indeks Investor33 pada Bursa Efek Indonesia periode 2015 - 2017. Sampel dalam penelitian ini di ambil menggunakan metode purposive sampling. Adapun proses pemilihan sampel pada penelitian ini menggunakan prosedur sebagai berikut:

\section{Tabel III-1 Prosedur Pemilihan Sampel}

\begin{tabular}{rlr} 
No & \multicolumn{1}{c}{ Distribusi Sampel } \\
\hline 1 & $\begin{array}{l}\text { Perusahaan yang terdaftar di } \\
\text { indeks Investor33 }\end{array}$ \\
& $\begin{array}{l}\text { Perusahaan yang tidak } \\
\text { membagikan deviden secara } \\
\text { kontinyu selama periode 2015- }\end{array}$ \\
& $\begin{array}{l}\text { Pe17 } \\
\text { Perusahaan yang tidak } \\
\text { menerbitkan data keuangan } \\
\text { lengkap sesuai kebutuhan } \\
\text { penelitian selama 2015 - 2017 }\end{array}$ \\
& Jumlah Sampel
\end{tabular}
Total
HASIL DAN PEMBAHASAN

Analisis Statistik Deskriptif

Descriptive Statistics

\begin{tabular}{lccccc}
\hline & N & Min & Max & Mean & $\begin{array}{c}\text { Std. } \\
\text { Deviation }\end{array}$ \\
\hline TATO & 54 &. & 3.32 & 1.0824 & .86689 \\
& & 1 & & & \\
CR & 54 & 48.16 & 598.91 & 193.7237 & 124.13471 \\
DER & 54 &. & 3.31 & 1.4113 & .84130 \\
& & 2 & & & \\
ROA & 54 & 1.18 & 38.16 & 9.4259 & 8.10490 \\
KEBIJAKAN & 54 & 6.69 & 99.88 & 37.8202 & 24.36253 \\
DIVIDEN & & & & & \\
$\begin{array}{l}\text { Valid N } \\
\text { (listwise) }\end{array}$ & 54 & & & & \\
\hline
\end{tabular}

Nilai paling rendah kebijakan dividen yang di ukur menggunakan Dividen Payout Ratio (DPR) sebesar 6,69 yang dimiliki oleh PT Sri Rejeki Isman Tbk. (SRIL) pada tahun 2016. Sedangkan nilai paling tinggi sebesar 99,88 yang dimiliki oleh PT. Unilever Indonesia Tbk (UNVR) pada tahun 2015. rata-rata sebesar 37,8202 dengan standar deviasi sebesar 24,36253. Sedangkan variabel Total Asset Turn Over (TATO) memiliki nilai paling rendah sebesar 0,11 yang dimiliki oleh PT. Jasa Marga (Persero) Tbk (JSMR) pada tahun 2017. Sedangkan nilai maksimum sebesar 3,32 yang dimiliki oleh PT. Tiphone Mobile Indonesia Tbk. (TELE) pada tahun 2016. TATO memiliki nilai mean sebesar 1, 0824 dengan standar deviasi sebesar 0,86689 .

Variabel Current Ratio (CR) memiliki nilai paling rendah sebesar 48,16 yang dimiliki oleh PT. Jasa Marga (Persero) Tbk pada tahun 2015, dan nilai paling tinggi sebesar 598,91 dimiliki oleh PT. Tiphone Mobile Indonesia Tbk. sedangkan nilai rata-rata nya sebesar 193,7237 dan standar deviasi sebesar 124, 13471. Variabel Debt to Equity Ratio (DER) memiliki nilai minimum sebesar 0,20 yang dimiliki oleh PT. Kalbe Farma Tbk, dan nilai maksimum sebesar 3,31 yang dimiliki oleh PT. Jasa Marga (Persero) Tbk. Nilai rata-rata sebesar 1,4113 serta standar deviasinya sebesar 0,84130 . Variabel Return On Assets (ROA) memiliki nilai minimum sebesar 1,18 yang dimiliki oleh PT. Sumber Alfaria Trijaya Tbk (AMRT), nalai maksimum sebesar 38,16 yang dimiliki oleh PT. 
${ }^{1}$ Bawon Triono, ${ }^{2}$ Dwi Artati

Unilever Indonesia Tbk dan nilai mean sebesar 9,4259 serta standar deviasinya sebesar 24,36253 .

\section{Uji Asumsi Klasik \\ Uji Normalitas}

Tabel IV-2 Hasil Uji Kolmogorov-Smirnov

One-Sample Kolmogorov-Smirnov Test

\begin{tabular}{|c|c|c|}
\hline & & $\begin{array}{l}\text { Standardized } \\
\text { Residual }\end{array}$ \\
\hline \multicolumn{2}{|l|}{$\mathrm{N}$} & 54 \\
\hline \multirow{3}{*}{$\begin{array}{l}\text { Normal } \\
\text { Parameters }{ }^{\mathrm{a}, \mathrm{b}}\end{array}$} & Mean & .0000000 \\
\hline & Std. & .96152395 \\
\hline & Deviation & \\
\hline \multirow{3}{*}{$\begin{array}{l}\text { Most Extreme } \\
\text { Differences }\end{array}$} & Absolute & .107 \\
\hline & Positive & .066 \\
\hline & Negative & -.107 \\
\hline \multicolumn{2}{|c|}{ Kolmogorov-Smirnov Z } & .784 \\
\hline \multicolumn{2}{|c|}{ Asymp. Sig. (2-tailed) } & .570 \\
\hline
\end{tabular}

a. Test distribution is Normal.

b. Calculated from data.

Sumber: Output SPSS 21, 2019

Berdasarkan tabel IV-1 output SPSS tersebut menunjukkan bahwa nilai signifikansi asymp.Sig. (2-tailed) sebesar 0,570>0,05. Sehingga dapat disimpulkan bahwa data berdistribusi normal.

\section{Uji Multikolinearitas}

Tabel IV-3 Nilai Collinearity Statstics

\begin{tabular}{llll}
\hline \multirow{2}{*}{ No } & $\begin{array}{l}\text { Variabel } \\
\text { Independen }\end{array}$ & \multicolumn{2}{l}{ Collinearity Statistics } \\
\cline { 2 - 3 } 1 & TATO & 0,678 & VIF \\
2 & $C R$ & 0,645 & 1,475 \\
3 & DER & 0,712 & 1,549 \\
4 & ROA & $\underline{0,844}$ & 1,404 \\
& &
\end{tabular}

Sumber: data diolah, 2019

Berdasarkan tabel IV-2 dapat diketahui bahwa pada kolom colliniearity statistic menunjukkan angka VIF tidak lebih besar dari 10 dan tolerance lebih dari 0,1. Berdasarkan hasil tersebut dapat diketahui bahwa model regresi ini tidak terdapat multikolinieritas, sehingga model dapat dipakai.

\section{Uji Autokorelasi}

\begin{tabular}{|l|r|}
\hline \multicolumn{2}{|c|}{ Runs Test } \\
\hline & $\begin{array}{c}\text { Unstandardized } \\
\text { Residual }\end{array}$ \\
\hline Test Value $^{\mathrm{a}}$ & 1.77668 \\
Cases < Test Value & 27 \\
Cases >= Test Value & 27 \\
Total Cases & 54 \\
Number of Runs & 24 \\
Z & -1.099 \\
Asymp. Sig. (2-tailed) & .272 \\
\hline
\end{tabular}

a. Median

Sumber: Output SPSS 21, 2019

Pada hasil output SPSS untuk uji runtest menunjukkan bahwa nilai asymtic significant uji run test sebesar 0.272 (lebih besar dari 0,05) maka tidak terdapat gejala atau masalah autokorelasi.

\section{Uji Heteroskedastisitas}

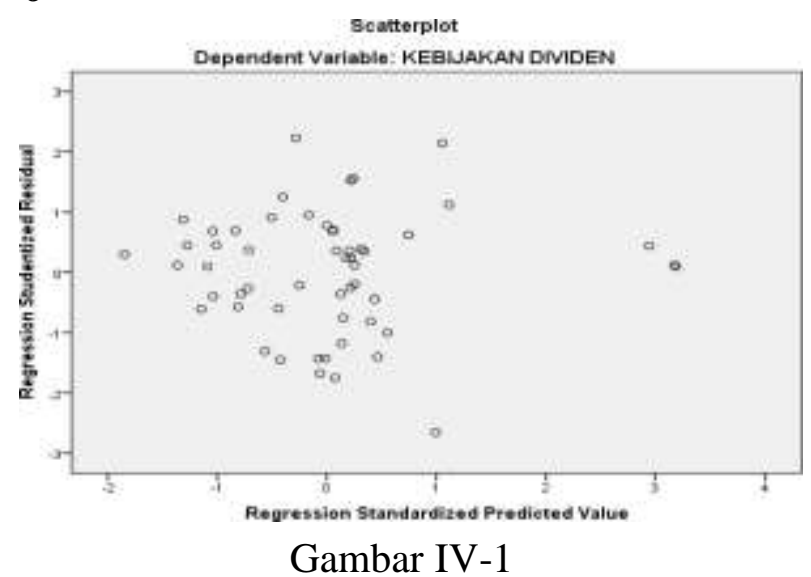

Berdasarkan Gambar IV-1 dapat dilihat bahwa titik - titik tidak membentuk suatu pola tertentu dan menyebar diatas dan dibawah angka 0 pada sumbu Y. Hal ini membuktikan bahwa tidak terjadi gejala heteroskedastisitas.

\section{Analisis Regresi Berganda}

Tabel IV-6 Regresi Berganda Hasil Hitungan SPSS

\begin{tabular}{cc}
\hline Notasi & Koefisien Regresi \\
\hline $\mathrm{a}$ & 42,202 \\
$\mathrm{~b}_{1}$ & 8,243 \\
$\mathrm{~b}_{2}$ & $-0,089$ \\
$\mathrm{~b}_{3}$ & $-8,196$ \\
$\mathrm{~b}_{4}$ & 1,647 \\
\hline
\end{tabular}

Sumber: data diolah, 2019 
${ }^{1}$ Bawon Triono, ${ }^{2}$ Dwi Artati

Berdasarkan tabel IV-5, maka dapat dibuat persamaan regeresinya sebagai berikut ini:

$$
\begin{aligned}
\mathrm{Y}= & 42,202+8,243 \mathrm{X}_{1}-0,089 \mathrm{X}_{2}-8,196 \mathrm{X}_{3} \\
& +1,647 \mathrm{X}_{4}+\mathrm{e}
\end{aligned}
$$

Persamaan di atas dapat dijelaskan sebagai berikut:

1. Konstanta (a) $=42,202$

Konstanta sebesar 42,202 berarti apabila variabel bebas (total asset turn over, current ratio, debt to equity ratio dan return on assets) bernilai 0 , maka nilai variabel kebijakan dividen sebesar 42,202.

2. $\mathrm{b}_{1}=8,243$

Koefisien regresi sebesar 8,243 artinya variabel total asset turn over $\left(\mathrm{X}_{1}\right)$ berpengaruh terhadap kebijakan dividen $(\mathrm{Y})$. Jika variabel total asset turn over $\left(\mathrm{X}_{1}\right)$ naik satu satuan sementara variabel independen lain tetap, maka variabel kebijakan dividen (Y) akan meningkat 8,243 .

3. $b_{2}=-0,089$

Koefisien regresi sebesar $-0,089$ artinya variabel current ratio $\left(\mathrm{X}_{2}\right)$ berpengaruh negatif terhadap kebijakan dividen (Y). Jika variabel current ratio $\left(\mathrm{X}_{2}\right)$ naik satu satuan sementara variabel independen lain tetap, maka variabel kebijakan dividen (Y) akan menurun 0,089 .

4. $b_{3}=-8,196$

Koefisien regresi sebesar $-8,196$ artinya debt to equity ratio $\left(\mathrm{X}_{3}\right)$ berpengaruh negatif terhadap kebijakan dividen (Y). Jika variabel debt to equity ratio $\left(\mathrm{X}_{3}\right)$ naik satu satuan sementara variabel independen lain tetap, maka variabel kebijakan dividen (Y) akan menurun 8,196.

5. $\mathrm{b}_{4}=1,647$

Koefisien regresi sebesar 1,647 artinya variabel return on assets $\left(\mathrm{X}_{4}\right)$ berpengaruh positif terhadap kebijakan dividen (Y). Jika variabel return on assets $\left(\mathrm{X}_{4}\right)$ naik satu satuan sementara variabel independen lain tetap, maka variabel kebijakan dividen (Y) akan meningkat 1,647 .

\section{Uji Hipotesis}

\section{Koefisien Determinasi}

Tabel IV-6 Uji koefisien Determinasi

\begin{tabular}{|c|c|c|c|c|}
\hline Model & $\mathrm{R}$ & $\begin{array}{c}\mathrm{R} \\
\text { Square }\end{array}$ & $\begin{array}{l}\text { Adjusted } \\
\text { R Square }\end{array}$ & $\begin{array}{l}\quad \text { Std. } \\
\text { Error of the } \\
\text { Estimate }\end{array}$ \\
\hline 1 & $.781^{\mathrm{a}}$ & .610 & .578 & 15.82849 \\
\hline \multicolumn{5}{|c|}{$\begin{array}{l}\text { a.Predictors: (Constant), ROA, CR, DER, } \\
\text { TATO }\end{array}$} \\
\hline \multicolumn{2}{|c|}{$\begin{array}{l}\text { b.Dependent } \\
\text { DIVIDEN }\end{array}$} & Vari & iable: & KEBIJAKAN \\
\hline
\end{tabular}
Model Summary ${ }^{\mathrm{b}}$

Sumber: Output SPSS 21, 2019

Berdasarkan tabel IV-6 dapat diketahui bahwa nilai Adjusted $R$ Square diperoleh nilai sebesar 0,578 atau $57,8 \%$. Hal ini menunjukkan bahwa $57,8 \%$ variasi variabel kebijakan dividen dijelaskan oleh vaiabel independen yaitu total asset turn over, current ratio, debt to equity ratio dan return on assets, Sedangkan 42,2\% kebijakan dividen dijelaskan oleh variabel lain yang tidak diteliti dalam penelitian ini.

\section{Uji T}

Coefficients $^{\mathrm{a}}$

\begin{tabular}{|c|c|c|c|c|c|}
\hline \multirow[t]{2}{*}{ Model } & \multicolumn{2}{|c|}{$\begin{array}{l}\text { Unstandardized } \\
\text { Coefficients }\end{array}$} & \multirow{2}{*}{$\begin{array}{c}\begin{array}{l}\text { Standardized } \\
\text { Coefficients }\end{array} \\
\text { Beta }\end{array}$} & \multirow[t]{2}{*}{$\mathrm{t}$} & \multirow[t]{2}{*}{ Sig. } \\
\hline & $\mathrm{B}$ & $\begin{array}{l}\text { Std. } \\
\text { Error }\end{array}$ & & & \\
\hline (Constant) & $42, .20$ & 27.660 & & 5.509 & .000 \\
\hline TATO & 8.243 & 3.046 & .293 & 2.706 & .009 \\
\hline $\mathrm{CR}$ & -.089 & .022 & -.454 & -4.086 & 000 \\
\hline DER & -8.196 & 3.062 & -.283 & -2.676 & 010 \\
\hline ROA & 1.647 & .292 & .548 & 5.638 & .000 \\
\hline
\end{tabular}

Tabel IV-7 Uji T

a. Dependent Variable: KEBIJAKAN DIVIDEN

Sumber: Output SPSS 21, 2019

Berdasarkan tabel IV-7, dapat dijelaskan hubungan antar variabel sebagai berikut:

1. Hubungan total asset turn over dan kebijakan dividen

Hasil uji t variabel total asset turn over di peroleh nilai thitung sebesar 2,706 $>\mathrm{t}_{\text {tabel }} 2,008$ dengan tingkat signifikansi sebesar $0,009<$ 0,05 . Hasil ini menunjukkan bahwa variabel 
${ }^{1}$ Bawon Triono, ${ }^{2}$ Dwi Artati

total asset turn over berpengaruh signifikan terhadap kebijakan dividen, sehingga dapat disimpulkan bahwa $\mathbf{H}_{1}$ diterima

2. Hubungan current ratio dan kebijakan dividen

Hasil uji t variabel current ratio di peroleh nilai $t_{\text {hitung }}$ sebesar $-4,086<\mathrm{t}_{\text {tabel }} 2,008$ dengan tingkat signifikansi sebesar 0,000 . Nilai signifikasi sebesar $0,000<0,05$, dengan demikian dapat dikatakan current ratio berpengaruh terhadap kebijakan dividen, sehingga dapat disimpulkan bahwa $\mathbf{H}_{2}$ diterima.

3. Hubungan debt to equity ratio dan kebijakan dividen.

Hasil uji $\mathrm{t}$ variabel debt to equity ratio diperoleh nilai $t_{\text {hitung }}-2,676<$ nilai $t_{\text {tabel }} 2,008$ dengan tingkat signifikansi sebesar $0,010<$ 0,05 . Hasil ini menunjukkan bahwa variabel debt to equity ratio berpengaruh terhadap kebijakan dividen, sehingga dapat disimpulkan bahwa $\mathbf{H}_{3}$ diterima.

4. Hubungan return on assets dan kebijkan dividen.

Hasil uji t variabel return on assets diperoleh nilai $t_{\text {hitung }} 5,638>$ nilai $t_{\text {tabel }} 2,008$ dengan tingkat signifikansi sebesar $0,000<0,05$. Hasil ini menunjukkan bahwa variabel return on assets berpengaruh signifikan terhadap kebijakan dividen, sehingga dapat disimpulkan bahwa $\mathbf{H}_{4}$ diterima.

\section{Uji F}

\begin{tabular}{cccccc}
\multicolumn{6}{c}{ Tabel IV-8 Uji F } \\
ANOVA $^{\mathrm{a}}$ & & \\
\hline Model & $\begin{array}{c}\text { Sum of } \\
\text { Squares }\end{array}$ & df & $\begin{array}{c}\text { Mean } \\
\text { Square }\end{array}$ & F & Sig. \\
& Squar & & \\
\hline Regression & 19180.728 & 4 & 4795.182 & 19.139 & $.000^{\mathrm{b}}$ \\
Residual & 12276.510 & 49 & 250.541 & & \\
Total & 31457.238 & 53 & & & \\
\hline
\end{tabular}

a. Dependent Variable: KEBIJAKAN DIVIDEN

b. Predictors: (Constant), ROA, CR, DER, TATO

Sumber: Output SPSS 21, 2019

Berdasarkan tabel IV-8, diperoleh nilai $F_{\text {hitung }}$ sebesar 19,139 dengan tingkat signifikan $0,000<0,05$. Selain itu, diketahui juga bahwa $F_{\text {hitung }}$ lebih besar dari $F_{\text {tabel }}$ yaitu sebesar 2,56, maka dapat disimpulkan bahwa secara bersama- sama variabel total asset turn over, current ratio, debt to equity ratio dan return on assets berpengaruh signifikan terhadap kebijakan dividen sehingga pada penelitian ini Hsditerima.

\section{Implikasi Manajerial}

\section{Pengaruh Total Asset Turn Over Terhadap Kebijakan Dividen Perusahaan pada Indeks Investor33.}

Berdasarkan analisis untuk variabel Total Asset Turn Over mempunyai pengaruh yang signifikan terhadap kebijakan dividen dengan nilai $t_{\text {hitung }} 2,706$ dan tingkat signifikansi sebesar $0,009<0,05$. Penelitan ini menunjukkan bahwa Total Asset Turn Over berpengaruh positif terhadap kebijakan dividen perusahaan pada indeks Investor33. Hal ini berarti semakin lancar perputaran total asetnya maka berdampak pada meningkatnya kebijakan dividen.

Total Asset Turn Over merupakan rasio yang mengukur perputaran semua aktiva yang dimiliki oleh perusahaan dan mengukur jumlah penjualan yang dihasilkan dari setiap rupiah aktiva (Kasmir, 2012:185). Semakin cepat perputaran aktiva, maka laba bersih yang dihasilkan akan semakin meningkat karena perusahaan sudah dapat memanfaatkan aktiva untuk meningkatkan penjualan yang berpengaruh terhadap pendapatan. Dengan demikian semakin efektif perputaran aset perusahaan menghasilkan kinerja perusahaan yang tinggi sehingga dapat meningkatan laba perusahaan dan berdampak pada peningkatan tingkat kembalian (return) yang didapat investor. Penelitian ini sejalan dengan penelitian Mahrina (2010) yang menyatakan bahwa Total Asset Turn Over berpengaruh terhadap kebijakan dividen.

\section{Pengaruh Current Ratio Terhadap Kebijakan Dividen Perusahaan pada Indeks Investor 33.}

Berdasarkan analisis untuk variabel current ratio berpengaruh terhadap kebijakan dividen dengan nilai thitung $-4,086$ dan tingkat signifikansi sebesar $0,000<0,05$. Penelitian ini menunjukkan bahwa current ratio berpengaruh negatif terhadap kebijakan 
${ }^{1}$ Bawon Triono, ${ }^{2}$ Dwi Artati

dividen perusahaan pada indeks Investor 33. Current Ratio (CR) merupakan rasio untuk mengukur kemampuan perusahaan dalam membayar kewajiban jangka pendeknya (Kasmir, 2012: 132).

Semakin tinggi Current Ratio semakin besar pula kemampuan perusahaan untuk melunasi utang jangka pendeknya. Namun, Current Ratio yang terlalu tinggi juga akan berdampak buruk bagi perusahaan. Apabila jumlah aktiva lancar terlalu banyak, itu artinya terdapat sebagian modal kerja perusahaan tidak berputar atau mengalami pengangguran, sehingga akan berpengaruh negatif terhadap kemampuan perusahaan dalam memperoleh laba (Martono, 2008: 55). Nilai Current Ratio yang terlalu tinggi mengisyaratkan banyaknya piutang perusahaan. Piutang perusahaan tersebut menyebabkan dana yang seharusnya dapat digunakan untuk operasional perusahaan menjadi tidak berputar untuk memperoleh laba yang maksimal dan berdampak pada menurunnya pembayaran dividen. Penelitian ini sesuai dengan penelitian yang dilakukan Nurhayati (2013) yang menyatakan bahwa Current Ratio berpengaruh negatif terhadap kebijakan dividen.

\section{Pengaruh Debt to Equity Ratio Terhadap Kebijakan Dividen Perusahaan pada Indeks Investor33.}

Berdasarkan analisis untuk variabel Debt to Equity Ratio berpengaruh terhadap kebijakan dividen karena nilai thitung $-2,676$ dengan tingkat signifikansi sebesar $0,010<$ 0,05 . Penelitian ini menunjukkan bahwa Debt to Equity Ratio berpengaruh negatif terhadap kebijakan dividen. Debt to Equity Ratio (DER) merupakan rasio untuk mengukur kemampuan perusahaan dalam memenuhi seluruh hutang. Semakin besar Debt to Equity Ratio menunjukan semakin tinggi kewajiban perusahaan dalam melunasi hutang. Semakin besar hutang sebuah perusahaan akan mempengaruhi tingkat pendapatan yang tersedia bagi pemegang saham, artinya, semakin tinggi kewajiban perusahaan akan menurunkan tingkat kemampuan untuk membayar dividen.

Menurut Kasmir (2012: 158) bahwa semakin besar Debt to Equity Ratio, akan semakin tidak menguntungkan karena akan semakin besar resiko yang ditanggung atas kegagalan yang mungkin terjadi di perusahaan. Debt to Equity Ratio adalah rasio yang menunjukan persentase penyediaan dana oleh pemegang saham terhadap pemberi pinjaman. Semakin besar Debt to Equity Ratio maka makin besar modal pinjaman sehingga akan menyebabkan semakin semakin besar pula beban hutang (biaya bunga) yang harus ditanggung perusahaan. Dengan demikian, Debt to Equity Ratio yang tinggi berdampak pada semakin kecilnya kemampuan perusahaan untuk membagikan dividen. Penelitian ini sejalan dengan penelitian yang dilakukan oleh Wahyuni (2018) yang menyatakan bahwa Debt to Equity Ratio berpengaruh terhadap kebijakan dividen.

\section{Pengaruh Return On Assets Terhadap Kebijakan Dividen Perusahaan pada Indeks Investor33.}

Berdasarkan analisis untuk variabel Return On Assets mempunyai pengaruh terhadap kebijakan dividen dengan nilai $\mathrm{t}_{\text {hitung }}$ 5,638 dan tingkat signifikansi sebesar $0,000<0,05$. Penelitian ini menunjukkan bahwa Return On Assets berpengaruh positif terhadap kebijakan dividen perusahaan pada indeks Investor33. Hal ini berarti semakin tinggi ROA maka kebijakan dividen semakin meningkat. Return On Assets (ROA) merupakan ukuran efektifitas perusahaan dalam menghasilkan keuntungan dengan memanfaatkan aktiva tetap yang digunakan untuk operasi Semakin besar Return On Assets (ROA) menunjukan kinerja perusahaan yang semakin baik, karena tingkat kembalian investasi (return) semakin besar.

Menurut Hery (2016:193) bahwa semakin tinggi hasil pengembalian atas aset berarti berarti semakin tinggi pula jumlah laba bersih yang dihasilkan oleh setiap rupiah dana yang tertanam dalam total aset. 
Dengan demikian, dapat disimpulkan bahwa semakin tinggi nilai ROA maka akan semakin tinggi kemampuan perusahaan dalam membagikan dividen. Penelitian ini sejalan dengan penelitian yang dilakukan oleh Wahyuni (2018) yang menyatakan bahwa Return On Assets berpengaruh positif terhadap kebijakan dividen.

5. Pengaruh total asset turn over, current ratio, debt to equity ratio, dan return on assets terhadap kebijakan dividen.

Berdasarkan hasil uji $F$ dalam penelitian ini diperoleh nilai $F_{\text {hitung }}$ sebesar $19,139>F_{\text {tabel }} 2,59$ dengan tingkat signifikansi sebesar $0,000<0,05$. Hal ini membuktikan bahwa variabel total asset turn over, current ratio, debt to equity ratio, dan return on assets secara bersama-sama berpengaruh signifikan terhadap kebijakan dividen perusahaan pada indeks Investor33. Artinya terdapat hubungan pengaruh variabel Total Asset Turn Over, Current Ratio, Debt to Equity Ratio dan Return On Assets secara bersama-sama terhadap Kebijakan Dividen perusahaan pada indeks Investor 33.

\section{PENUTUP}

\section{Simpulan}

Berdasarkan hasil analisis data mengenai pengaruh total asset turn over, current ratio, debt to equity ratio dan return on assets terhadap kebijakan dividen perusahaan yang termasuk pada Indeks Investor33 periode 2015- 2017, maka dapat diambil kesimpulan sebagai berikut:

1. Berdasarkan hasil analisis di atas dapat diketahui bahwa variabel total asset turn over berpengaruh positif terhadap kebijakan dividen. Dengan demikian $\mathrm{H}_{0}$ ditolak dan $\mathrm{H}_{1}$ diterima yang berarti bahwa peningkatan total asset turn over maka akan terjadi peningkatan kebijakan dividen.

2. Berdasarkan hasil analisis di atas dapat diketahui bahwa variabel current ratio berpengaruh negatif signifikan terhadap kebijakan dividen. Dengan demikian $\mathrm{H}_{0}$ ditolak dan $\mathrm{H}_{2}$ diterima yang berarti bahwa peningkatan current ratio maka akan terjadi penurunan kebijakan dividen.

3. Berdasarkan hasil analisis di atas dapat diketahui bahwa variabel debt to equity ratio berpengaruh negatif terhadap kebijakan dividen. Dengan demikian $\mathrm{H}_{0}$ ditolak dan $\mathrm{H}_{3}$ diterima yang berarti bahwa peningkatan Debt to Equity Ratio maka akan terjadi penurunan kebijakan dividen.

4. Berdasarkan hasil analisis di atas dapat diketahui bahwa variabel return on assets berpengaruh positif terhadap kebijakan dividen. Dengan demikian $\mathrm{H}_{0}$ ditolak dan $\mathrm{H}_{3}$ diterima yang berarti bahwa peningkatan return on assets maka akan terjadi peningkatan kebijakan dividen.

5. Secara simultan variabel total asset turn over, current ratio, debt to equity ratio dan return on assets berpengaruh signifikan terhadap kebijakan dividen sebesar $57,8 \%$ sedangkan sebesar 42,2\% dipengaruhi oleh variabelvariabel lain yang tidak diteliti dalam penelitian ini.

\section{Saran}

Berdasarkan kesimpulan dari penelitian ini maka penulis memberikan saran sebagai berikut:

1. Bagi manajemen perusahaan

Hasil penelitian ini menunjukkan bahwa current ratio berpengaruh negatif terhadap kebijakan dividen. Hendaknya perusahaan juga memperhatikan faktor-faktor lain yang berkaitan dengan kebijakan dividen. Meskipun kebanyakan investor menilai kinerja keuangan dari besarnya nilai likuiditas (current ratio) perusahaan, akan tetapi terlalu tinggi nilai likuiditas (current ratio) justru berpengaruh negatif terhadap kebijakan dividen.

2. Bagi Investor

Sebelum melakukan investasi, investor diharapkan memperhatikan tingkat perputaran aset, likuiditas perusahaan, rasio utang perusahaan serta return on assets, karena variabel tersebut akan mempengaruhi kinerja perusahaan yang akan berdampak 
${ }^{1}$ Bawon Triono, ${ }^{2}$ Dwi Artati

pada besar atau kecilnya dividen yang akan dibagian kepada pemilik saham.

3. Bagi Peneliti Selanjutnya

Penelitian selanjutnya disarankan untuk menambah variabel lain yang berhubungan dengan kebijakan dividen. Sehingga dapat memberikan gambaran yang lebih luas mengenai faktor apa saja yang mempengaruhi kebijakan dividen selain Total Asset Turn Over, Current Ratio, Debt to Equity Ratio, dan Return On Assets. Selain itu penelitian selanjutnya juga disarankan untuk memperluas sampel dan memperpanjang periode penelitian untuk memprediksi kebijakan dividen untuk tahun mendatang.

\section{REFERENSI}

Ghozali, I. (2013). Aplikasi Analisis Multivariate dengan Program IBM SPSS 21. Edisi Ketujuh. Semarang: Badan Penerbit Universitas Diponegoro.

Hanafi, M., \& Halim, A. (2014). Analisis Laporan Keuangan. Edisi Keempat. Yogyakrta: STIM YKPN.

Harahap, S. S. (2012). Analisa Kritis Atas Laporan Keuangan. Jakarta: PT. Raja Grafindo Persada.

Husnan, S., \& Pudjiastuti, E. (2006). Dasar Dasar Manajemen Keuangan. Yogyakarta: UPP STIM YKPN.

Jensen, \& Meckling. (1976). The Theory of The Firm: Manajerial Behaviour, Agency Cost, and Ownership Structur. Journal of Financial and Economics, 3:305-360.

Kasmir. (2012). Analisis Laporan Keuangan. Cetakan Keenam. Jakrta: PT. Raja Grafindo Persada.

Margaretha, F. (2005). Teori dan Aplikasi Manajemen Keuangan Investasi Sumber Dana Jangka Panjang. Jakarta: PT. Grasindo.

Martono, \& Harjito, A. (2008). Manajemen Keuangan, edisi 1. Yogyakarta: EKONISIA. Munawir. (2010). Analisis Laporan Keuangan.

Cetakan Kelima Belas. Liberty Yoyakarta: Yogyakarta.

Nuraini, S. (2016). Pengaruh Total Asset Turn Over, Current Ratio, Debt to Equity Ratio, dan Return On Asset Terhadap Kebijakan Dividen. Artikel Ilmiah, STIE PERBANAS SURABAYA.

Nurhayati, M. (2013). Pengaruh Size, Return On Asset, Current Ratio terhadap Price to Book Value Melalui Dividen Payout Ratio.

OKEfinance. (2014, April 07). Diambil kembali dari economy.okezone.com: economy.okezone.com/read/2014/04/07/226 1966365/indeks-investor33-menambahacuan-investasi. tangal 26 April 2019, jam 14.58 wib.

Prastowo, D. (2011). Analisis Laporan Keuangan, Teknik dan Aplikasi. Edisi Tiga. Yogyakarta: STIE YKPN.

Prihadi, T. (2014). Analisis Laporan Keuangan Teori dan Aplikasi. Jakarta: PPM.

Rahmawati, E. (2011). Pengaruh Current Ratio, ROA, Kebijakan Utang dan Ukuran Perusahaan Terhadap Kebijakan Dividen Menggunakan Regresi Logistik. Skripsi.

Rahmawati, N. D., Saerang, I., \& Rate, P. V. (2014). Kinerja Keuangan Pengaruhnya Terhadap Kebijakan Dividen Pada Perusahaan BUMN di Bursa Efek Indonesia. Jurnal EMBA Vol. 2, No. 2.

Riyanto, B. (2010). Dasar - dasar Pembelajaran Perusahaan. Yogyakarta: Yayasan Badan Penerbit Gajah Mada.

Sanjari, T. (2014). The Study Factor Influencing Corporate Dividen Policy of Financial and Non-Financial Firm on Companies Listed In Tehran Stock Exchange. Research Jurnal of Finance and Accounting, Vol.5, No.21.

Santoso, S. (2000). Latihan SPSS Statistik Parmetik. Jakarta: Gramedia.

Sartono, A. (2008). Manajemen Keuangan: Teori dan Aplikasi. Yogyakarta: BPFE.

Sartono, A. (2014). Manajemen Keuangan Teori dan Aplikasi. Yogyakarta: BPFE.

Silviana, C., Hidayat, R., \& Nuzula, N. F. (2014). Analisis Variabel-Variabel yang Mempengaruhi Kebijakan Dividen (Studi Pada Saham LQ45 di BEI Periode 20122012). Jurnal Administrasi Bisnis (JAB), Vol. 15, No. 1.

Sunariyah. (2010). Pengantar Pengetahuan Pasar Modal. Yogyakarta: UPP STIM YKPN. 
Sundjaja, R., \& Barlin. (2010). Manajemen Keuangan Dua. Edisi Kelima. Jakarta: PT. Prenhallindo.

Susetyo, A. 2017. Analisis Pengaruh Current Ratio, Debt to Equity Ratio, dan Total Asset Turn Over Terhadap Return On Asset Pada Perusahaan yang Tercatat di Jakarta Islamic Index. Jurnal Ilmiah Akuntansi dan Keuangan, Vol.6, No. 01, Bulan Juli, 132133.

Sutrisno. 2007. Manajemen Keuangan Teori, Konsep dan Aplikasi. Edisi Pertama. Cetakan Kedua. Yogyakarta: Ekonisia.

Wahyuni, S. F., \& Hafiz, M. S. (2018). Pengaruh CR, DER, dan ROA Terhadap DPR pada Perusahaan Manufaktur di BEI. Jurnal Ekonomi dan Syariah, Vol 1, No 2.

Warsono. (2003). Manajemen Keuangan Perusahaan Jilid1. Malang: Bayu Media Publishing.

Wati, T. A. (2015). Pengaruh Return On Asset, Debt to Equity Ratio, Collateral Asset dan Pertumbuhan Asset Terhadap Kebijakan Dividen Perusahaan Manufaktur yang Terdaftar di BEI. Skripsi.

Wild, J. J. (2014). Analisis Laporan Keuangan. Edisi Sepuluh. Jakarta: Salemba Empat.

www.idx.co.id. 